\title{
PENGARUH PENDAPATANMASYARAKAT TERHADAP \\ KONSUMSI DAGING SAPI DI DESA KOTABUNAN KECAMATAN KOTABUNAN KABUPATEN BOLAANG MONGONDOW TIMUR
}

\author{
Muh. Anshar. Tadete, F.H.Elly*, L.S. Kalangi dan R. Hadju
}

Fakultas Peternakan Universitas Sam Ratulangi Manado, 95115

\begin{abstract}
ABSTRAK
Konsumsi dagingsapi oleh masyarakat cenderung meningkat sesuai dengan peningkatan pendapatan. Permasalahannya apakah perubahan pendapatan masyarakat berpengaruh terhadap konsumsi daging sapi tersebut. Tujuan penelitian ini untuk mengetahui pengaruh pendapatan terhadap konsumsi daging sapi. Penelitian dilaksanakan di Desa Kotabunan Kecamatan Kotabunan Kabupaten Bolaang Mongondow Timur. Metode pengumpulan data menggunakan metode survei. Data yang digunakan adalah data primer dan sekunder. Penentuan sampel desa dilakukan secara purposive sampling yaitu desa yang memiliki jumlah penduduk terbanyak dan berada di pesisir pantai. Penentuan responden berdasarkan simple random sampling. Jumlah responden sebanyak 44 rumahtangga. Variabel yang diukur adalah jumlah konsumsi daging sapi dan jumlah pendapatan. Metode analisis yang digunakan adalah analisis regresi sederhana. Berdasarkan hasil penelitian, pendapatan responden secara keseluruhan adalah Rp. 143.070.000 dengan rata-rata Rp. 3.251.590,9/rumah tangga/bulan. Jumlah konsumsi daging sapi 63.5 $\mathrm{Kg} / \mathrm{bulan}$. Rata-rata pengeluaran responden untuk mengkonsumsi daging sapi sebesar Rp. 134.886,36 atau $4.9 \%$ dari pendapatan keluarga. Konsumsi protein hewani asal ternak sebanyak 6 gram/kapita/hari atau setara dengan 10,3 $\mathrm{kg}$ daging/kapita/tahun, 6,5 $\mathrm{kg}$ telur /kapita/tahun, dan 7,2 kg susu/kapita/tahun

\footnotetext{
*Korespondensi (corresponding Author)

Email : femi_elly@yahoo.co.id
}

juga masih belum tercapai. Berdasarkan hasil penelitian dapat disimpulkan bahwa pendapatan berpengaruh nyata terhadap konsumsi daging Sapi di Desa Kotabunan KecamatanKotabunan Kabupaten Kepulauan Bolaang Mongondow Timur..

Kata kunci : pendapatan, konsumsi, daging sapi

\section{ABSTRACT}

$\begin{array}{llrr}\text { EFFECT OF INCOME } & \text { ON BEEF } \\ \text { CONSUMPTION IN } & \text { KOTABUNAN } \\ \text { VILLAGE EAST } & \text { BOLAANG } \\ \text { MONGONDOW } & & \text { REGENCY. }\end{array}$
Consumption of beef by society tends to increase in line with their income. The problem is whether people's income changes affect beef consumption. The purpose of this study was to analyze the effect of income on beef consumption. Research has been conducted in the village of Kotabunan, District of Kotabunan East Bolaang Mongondow Regency.The data collection was conducted using a survey method. The data used are primary and secondary data. Determination of the sample villages have been done by purposive sampling, the village which has the largest population, and in the coastal area. Sample was selected by simple random sampling. The number of respondents as many as 44 households..Simple regression analysis was used to meet the goal of this study. Based on the results showed total incomes of respondents Rp. 143,070,000 with an average of Rp. 3,251,590.9/household /month. Total beef consumption $63.5 \mathrm{Kg} /$ month, with an average expenditure of
\end{abstract}


respondents to consume beef $\mathrm{Rp}$. $134,886.36$ or $4.9 \%$ of family income. Consumption of animal protein from livestock as much as 6 grams / capita / day, equivalent to $10.3 \mathrm{~kg}$ of meat / capita / year, $6.5 \mathrm{~kg}$ of eggs / capita / year, and $7.2 \mathrm{~kg}$ milk / capita / year is still not achieved. Based on the results of this study concluded that incomes significantly affect the consumption of beef in the village Kotabunan, District Kotabunan, East Bolaang Mongondow Regency.

Keywords : income, consumption, beef

\section{PENDAHULUAN}

Perkembangan konsumsi daging sapi per kapita untuk masyarakat Indonesia dari tahun 1993 hingga tahun 2014 berfluktuasi dan cenderung naik. Data Susenas BPS (2014), menunjukkan bahwa pada tahun 1993 tingkat konsumsi daging sapi masyarakat Indonesia sebesar $0,704 \mathrm{~kg} / \mathrm{kapita} / \mathrm{tahun}$ dan pada tahun 2014 naik menjadi 2.36 $\mathrm{kg} / \mathrm{kapita} / \mathrm{tahun}$. Standar konsumsi daging sapi yang dicanangkan FAO tahun 2008 yaitu sebesar $33 \mathrm{~kg} / \mathrm{kapita} / \mathrm{tahun}$. Konsumsi daging sapi di Indonesia masih jauh dari standar yang FAO, dan masih sangat rendah jika dibandingkan dengan negara-negara lain, seperti Argentina dengan tingkat konsumsi daging sapinya mencapai 55 kg/kapita/tahun, Singapura mencapai $15 \mathrm{~kg}$ per kapita per tahun, Filipina $7 \mathrm{~kg}$ per kapita per tahun. Daging pada umumnya memiliki kandungan protein yang berguna dalam memenuhi standar konsumsi masyarakat.Standar konsumsi kebutuhan protein pada anak balita 2-2,5 gram perkilogram berat badan, sedangkan pada orang dewasa hanya 1 gram perkilogram berat badan (Rasyaf, 2000). Berdasarkan hasil Widya Karya Pangan dan Gizi tahun 2004 norma gizi protein hewani dianjurkan 15 gram/kapita/hari terdiri dari 9 gram/kapita/hari berasal dari komoditi perikanan dan 6 gram/kapita/hari berasal dari komoditi peternakan. Konsumsi protein hewani asal ternak sebanyak 6 gram/kapita/hari atau setara dengan 10,3 $\mathrm{kg}$ daging/kapita/tahun, 6,5 $\mathrm{kg}$ telur /kapita/tahun, dan 7,2 kg susu/kapita/tahun juga masih belum tercapai (Direktorat Jendral Peternakan, 2006). Konsumsi protein hewani asal ternak di Sulawesi Utara belum memenuhi standar yaitu baru sebesar 4,84 gr/kapita/hari sedangkan untuk konsumsi protein asal ikan sudah sebesar 14,41 gr/kapita/hari sudah diatas anjuran Widya Karya Pangan dan Gizi (Dinas Ketahanan Pangan Sulut, 2010).

Desa Kotabunan merupakan salah satu wilayah yang ada di Kecamatan Kotabunan Kabupaten Bolaang Mongondow Timur provinsi Sulawesi Utara. Desa Kotabunan yang merupakan salah satu daerah pesisir pantai memiliki jumlah penduduk 1.444 jiwa yang terdiri dari V lima dusun dan 445 KK. 
Masyarakat yang berada di Desa Kotabunan mayoritas bekerja sebagai petani dan nelayan. Mata pencaharian masyarakat juga sebagai penambang, hanya sebagian kecil yang berprofesi sebagai Pegawai Negeri Sipil dan pedagang. Perilaku masyarakat dalam mengkonsumsi daging sapi menyesuaikan dengan tingkat pendapatan yang diperoleh. Menurut Rachman (2001), pola konsumsi dan pengeluaran rumah tangga umumnya berbeda antara agoekosistem, antar kelompok pendapatan, antar etnis, atau suku dan antar waktu. Perubahan tingkat pendapatan akan mempengaruhi banyaknya daging yang dikonsumsi bahkan seringkali dijumpai dengan bertambahnya pendapatan maka masyarakat cenderung mengkonsumsi barang yang kualitasnya lebih baik. Peningkatan pendapatan merupakan salah satu faktor yang mendorong masyarakat untuk mengubah pola konsumsi dengan perubahan kualitas gizi yang lebih baik (Amir et al, 2006). Permasalahannya apakah tingkat pendapatan masyarakat desa Kotabunan dapat mempengaruhi perilaku konsumsi mereka terhadap daging sapi. Berdasarkan latar belakang dan permasalahan, maka dirumuskan masalah apakah pendapatan berpengaruh terhadap konsumsi daging sapi di Desa Kotabunan. Penelitian ini bertujuan untuk mengetahui seberapa besar konsumsi daging sapi dan, berapa besar pendapatan rumah tangga di Desa Kotabunan serta, pengaruh pendapatan terhadap konsumsi daging sapi di Desa Kotabunan.

\section{METODE PENELITIAN}

Penelitian ini telah dilaksankan di Desa Kotabunan Kecamatan Kotabunan Kabupaten Bolaang Mongondow Timur pada bulan Desember 2015 sampai Januari 2016. Penelitian telah dilakukan menggunakan metode servei. Data yang diperoleh adalah data primer dan sekunder. Data primer diperoleh dari langsung dari responden mealui wawancara dengan menggunakan daftar pertanyaan/kuosioner. Data primer menyangkut identitas responden (nama, umur, pendidikan, pekerjaan dan jumlah anggota keluarga), tingkat pendapatan keluarga dan jumlah konsumsi daging sapi. Sedangkan data sekunder diperoleh dari instansi yang terkait dengan penelitian ini, di antaranya Dinas Pertanian dan Peternakan Sulawesi Utara, Badan Pusat Statistik, Kantor Kecamatan Kotabunan dan Kantor Desa Kotabunan. Penentuan sampel desa dilakukan secara purposive sampling yaitu desa yang memiliki jumlah penduduk yang paling banyak dan berada dipesisir pantai. Responden ditentukan secara simple random sampling (Arikunto, 2002 ; Daniel, 2001) yaitu sampel yang diambil 
secara acak sederhana sebanyak $10 \%$ dari jumlah rumah tangga (Tabel 1).

Tabel 1. Dusun, Jumlah KK, dan Jumlah Responden di Desa Kotabunan

\begin{tabular}{lcrr}
\hline & Dusun & $\begin{array}{c}\text { Jumlah Kepala } \\
\text { Keluarga }\end{array}$ & $\begin{array}{c}\text { Jumlah } \\
\text { Responden }\end{array}$ \\
\hline & I & 100 & 10 \\
& II & 72 & 7 \\
& III & 60 & 6 \\
& IV & 119 & 12 \\
& V & 94 & 9 \\
\hline Jumlah & & 445 & 44 \\
\hline
\end{tabular}

Variabel dan pengukurannya dalam penelitian ini sebagai berikut: (a) Konsumsi daging yaitu jumlah daging mentah yang dibeli dan dikonsumsi selama 1 (satu) bulan oleh seluruh anggota keluarga, diukur dalam satuan $\mathrm{kg} / \mathrm{bulan}$; (b) Pendapatan yaitu jumlah penerimaan seluruh anggota keluarga selama 1 (satu) bulan, diukur dalam satuan $\mathrm{Rp} / \mathrm{bulan}$. Analisis data yang digunakan dalam menjawab tujuan penelitian ini adalah analisis regresi sederhana seperti terlihat pada pesamaan (1).

$$
C=\mathbf{a}+\mathbf{b} Y+e
$$

\section{HASIL DAN PEMBAHASAN}

Produk peternakan berupa daging, telur dan susu sangat dibutuhkan dalam menopang kehidupan tubuh manusia mengarah ke kualitas sumberdaya manusia yang lebih baik. Kenyataannya konsumsi pangan hewani produk peternakan belum dapat dipenuhi masyarakat pedesaan termasuk masyarakat daerah pesisir. Kondisi ini seperti yang dinyatakan
Cahyani et al (2008), bahwa masyarakat masih tergantung pada sumber pangan karbohidrat. Selanjutnya dikemukakan bahwa konsumsi beras masih sangat tinggi (lebih dari 60\%), sementara konsumsi pangan hewani khususnya asal ternak masih sangat rendah.

Hasil penelitian menunjukan bahwa pendapatan responden bervariasi yaitu terendah Rp. 750.000 /bulan, sedangkan yang tertinggi Rp. 9.900.000 /bulan. Jumlah pendapatan responden secara keseluruhan Rp. 143.070.000 dengan rata-rata Rp. 3.251.591 /rumah tangga per bulan. Rata-rata pendapatan rumah tangga per bulan masih lebih tinggi dibandingkan hasil penelitian (Elly et al, 2013) yang menunjukan bahwa rata-rata pendapatan rumah tangga masyarakat pesisir di Kabupaten Minahasa sebesar Rp 3.123.700 /bulan. Secara teori bahwa semakin tinggi pendapatan menyebabkan konsumsi cenderung meningkat (Sugiarto et al, 2002). Suyastiri (2008) mengemukakan bahwa konsumsi rumah 
tangga khususnya pangan dipengaruhi oleh pendapatan, harga bahan pangan, jumlah anggota keluarga dan pendidikan. Menurut Sayekti (2008), perbedaan pendapatan akan mempengaruhi konsumsi dan pola konsumsi rumah tangga.

Hasil penelitian menunjukkan bahwa jumlah konsumsi daging sapi 63,5 $\mathrm{kg}$ per bulan dengan jumlah 44 kepala keluargaa atau 178 responden. Rata-rata pengeluaran responden untuk mengkonsumsi daging sapi sebesar Rp. 134.886,36 atau $4.9 \%$ dari pendapatan keluarga. Rata-rata pengeluaran responden dalam mengkonsumsi daging sapi sebesar Rp. 136.023.

Konsumsi daging sapidi Desa Kotabunan Kecamatan Kotabunan Kabupaten Bolaang Mongondow Timur sebesar 4,43 kg/kapita/tahun menunjukan $43 \%$ dari standar target nasional yaitu sebesar sebesar 10,3 $\mathrm{kg}$ daging secara umum/kapita/tahun (Dinas pertanian dan Peternakan SULUT, 2011). Dengan demikian jika dibandingkan dengan konsumsi daging secara umum konsumsi daging sapi di Desa Kotabunan masih terdapat kekurangan $57 \%$ dari yang dianjurkan. Kekurangan ini bisa diisi dengan konsumsi daging lainnya.

Konsumsi daging sapi sebesar 4,43 $\mathrm{kg} / \mathrm{kapita} /$ tahun tersebut menunjukkan masih sangat rendah jika dibandingkan masyarakat yang berada dinegara-negara lain. Konsumsi daging sapi yang dicanangkan FAO tahun 2008 yakni 33 $\mathrm{kg} / \mathrm{kapita} / \mathrm{tahun}$ untuk mengurangi kekurangan gizi masyarakat dunia. Gizi adalah salah satu faktor penentu penyakit. Pola makan dan kebiasaan makan adalah kunci pencegahan penyakit (Nilsen et al. 2010). Kekurangan gizi seseorang tergantung pada factor social ekonomi. Verecken et al (2005) dalam penelitiannya menggaris bawahi pentingnya faktor sosial ekonomi dalam kaitannya dengan kebiasaan makan. Hasil penelitian Maillot et al (2007) menunjukkan bahwa makanan berkualitas tinggi lebih mahal karena memiliki kepadatan energi rendah dan kaya nutrisi. Kualitas makanan dipengaruhi oleh socioeconomis status (SES) (Darmon and Drewnowski, 2008). Perbedaan socio-economic position (SEP) rendah dan tinggi dalam mengkonsumsi pangan juga telah diteliti oleh Ball et al (2009). Masyarakat dengan socioeconomis status (SES) rendah memiliki ekonomi terbatas. Frekuensi konsumsi makanan juga berbeda menurut negara dan gender (Mikolajczyk, 2009). Demikian pula Sandvik et al (2010) menguji socioeconomic status (SES) dalam pola konsumsi.

Hasil penelitian menunjukkan bahwa masyarakat di Desa Kotabunan 
memiliki bawaan atau kebiasaan secara turun-temurun dalam mengkonsumsi protein hewani asal ternak diantaranya daging sapi. Kebiasaan masyarakat seperti ini sudah ada sejak zaman Kerajaan Bolaang Mongondow dan sampe saat ini masih terlihat. Tetapi, masyarakat di era moderenisasi saat ini cenderung mengurangi konsumsi daging dengan alasan yang berkaitan dengan masalah kesehatan. Kondisi ini seperti yang dinyatakan Tanziha (2009) bahwa kemampuan untuk menyediakan pangan yang layak dan sesuai dengan kecukupan gizi yang dianjurkan juga semakin menurun. Beberapa hasil penelitian menunjukkan bahwa pentingnya makanan berkualitas perlu disosialisasikan dan berbagai cara telah dilakukan di negara maju. Penelitian Leganger (2003) mempelajari hubugan pendidikan dengan perilaku kesehatan. Promosi kesehatan dalam hal ini lebih tampak untuk perilaku socialeconomic status yang tinggi. Masyarakat tertentu cenderung menggunakan internet sebagai mediator untuk kesehatan dan hal ini berkaitan dengan socio-economic status (SES) (Wangberg et al. 2008). Promosi dan pendidikan kesehatan bahkan telah dilakukan melalui promosi online (Duperel et al, 2010). Profil nutrisi berkaitan dengan pemahaman konsumen tentang ilmu pengetahuan dan potensi untuk menfasilitasi keputusan makanan sehat telah diteliti oleh Gerrior (2010).

Berdasarkan data dari Direktur Pengembangan Sumberdaya dan Lingkungan Hidup (PSDLH) Kemendes (2016) bahwa konsumsi daging sapi orang Indonesia hanya $2,2 \mathrm{~kg} / \mathrm{kapita} / \mathrm{tahun}$ dan termasuk masih rendah. Data konsumsi daging sapi tersebut didukung kajian BKP dan Ditjen Peternakan dan Kesehatan Hewan (2011).

Hasil penelitian yang diperoleh menunjukkan bahwa dikonsumsi oleh masyarakat Desa Kotabunan sebanyak $63,5 \mathrm{~kg}$ atau 4,43 kg/kapita/tahun dengan rata-rata $0,369 \mathrm{~kg} / \mathrm{kapita} / \mathrm{bulan}$. Hal ini masih jauh di bawah capaian konsumsi daging oleh masyarakat kota Manado dan Sulawesi Utara pada umumnya. Data Dinas Ketahanan Pangan Sulawesi Utara (2011) menunjukkan bahwa konsumsi daging yang telah dicapai di Sulawesi Utara sebesar 10,37 $\mathrm{kg} / \mathrm{kapita} / \mathrm{tahun}$, sedangkan konsumsi di Kota Manado sebesar 15,3 kg/kapita/tahun. Hasil penelitian Ambat (2011) menunjukkan bahwa konsumsi daging di Kota Manado sudah kelebihan 48,5 \% dari konsumsi yang dianjurkan secara nasional.

Hasil analisis regresi pengaaruh pendapatan terhadap konsumsi daging sapi dapat pada persamaan (2) : 


$$
\mathrm{C}=-0.256+0.500 \mathrm{Y}
$$

Nilai a (intersep) sebesar -0.256 , artinya apabila pendapatan responden dan keluarganya tidak berubah maka konsumsi daging sapi cenderung berkurang sebesar 0.256 gram per bulan. Nilai koefisien regresi dari variabel pendapatan (b) sebesar 0.500 artinya bila pendapatan naik Rp 1000 naka konsumsi daging sapi akan naik sekitar 500 gram. Nilai $t_{\text {hit }}$ yang diperoleh adalah 4.723 pada taraf signifikan 0.000 , artinya secara statistik perubahan pendapatan berpengaruh nyata terhadap perubahan konsumsi daging sapi (ceteris paribus). Hal ini sejalan dengan teori ekonomi bahwa semakin tinggi pendapatan maka konsumsi suatu barang akan semakin tinggi (Sugiarto et al, 2002). Semakin tinggi pendapatan maka kecenderungan untuk mengkonsumsi daging sapi semakin tinggi di Desa Kotabunan Kecamatan Kotabunan Kabupaten Bolaang Mongondow Timur. Hasil ini ditunjang oleh penelitian Osak (2014), yang menunjukkan bahwa pendapatan berpengaruh nyata terhadap konsumsi daging.

\section{KESIMPULAN}

Berdasarkan hasil penelitian dapat disimpulkan bahwa :

1. Konsumsi daging sapidi Desa Kotabunan Kecamatan Kotabunan
Kabuapten Bolaang Mongondow

Timur sebesar 4,43 kg/kapita/tahun menunjukan $43 \%$ dari standar target nasional yaitu sebesar sebesar $10,3 \mathrm{~kg}$ daging secara umum/kapita/tahun.

2. Jumlah pendapatan responden secara keseluruhan Rp. 143.070.000 dengan rata-rata Rp. 3.251.591/rumah tangga /bulan.

3. Pendapatan berpengaruh nyata terhadap konsumsi daging sapi masyarakat Desa Kotabunan Kecamatan Kotabunan Kabupaten Bolaang Mongondow Timur.

Berdasarkan hasil penelitian disarankan perlu dilakukan penelitian lebih lanjut tentang konsumsi protein hewani khususnya daging sapi beserta faktorfaktor yang mempengaruhinya.

\section{DAFTAR PUSTAKA}

Ambat, A. 2011. Konsumsi Daging di Kota Manado. Skripsi. Fakultas Peternakan, Unsrat, Manado

Amir, A., S. Widodo dan S. Hardyastuti. 2006. Analisis konsumsi daging sapi pada tingkat rumahtangga di Sulawesi Tenga. Agrosains, 19 (4). Oktober 2006. P435-449.

Arikunto, S. 2002. Prosedur Penelitian, Suatu Pendekatan Praktek. Edisi Revisi V. Bina Aksara. Yogyakarta.

Ball, K., A. MacFarlane, D. Crawford, G. Savige, N. Andrianopoulos and A. Worsley. 2009. Can social cognitive theory constructs explain socioeconomic variations in adolescent 
eating behaviours? A mediation analysis. Health Educ. Res.(2009) 24 (3): 496-506.

Cahyani, G.I. B. Suryanto dan Mukson. 2008. Analisis Faktor Sosial Ekonomi Keluarga terhadap Keanekaragaman Konsumsi Pangan Berbasis Agribisnis di Kabupaten Banyumas. Jurnal Agribisnis. 2008.

Darmon, N and A. Drewnowski. 2008. Does social class predict diet quality? Am J of Clin Nutr, 2008. Vol. 87, No. 5 (May) p: 1107-1117.

Dinas Pertanian dan Peternakan SULUT. 2011. Laporan Dinas Pertanian dan Peternakan Provinsi Sulawesi Utara, Manado.

Dinas Ketahanan Pangan SULUT. 2011. Statistik Konsumsi Protein Hewani Dinas Ketahanan Pangan Sulawesi Utara, Manado.

Direktorat Jenderal Peternakan. 2006. Pembangunan Jangka Panjang Kedua Peternakan. Dirjen Peternakan, Departemen Pertanian, Jakarta.

Dupere1, S., S. Courchesne-O'Neill, and M. O'Neill. 2010. Building capacity through the internet: lessons learnt from the Reviews of Health Promotion \& Education Online. Health Promot. Int. 2010. 25 (1). p: 107-114.

Elly, F.H., M.A.V. Manese, I.D.R. Lumenta, dan N.M. Santa. 2013. Analisis Konsumsi Pangan Produk Peternakan Rumahtangga Pesisir Pantai di Kabupaten Minahasa Selatan. $\quad$ p: 123-129. http://lppm.unmas.ac.id/wpcontent/uploads/2014/06/20-FEMIH.ELLY I.D.R.LUMENTAKL1.pdf. Diakses 10 November $\underline{2015 .}$
Gerrior, S.A. 2010. Nutrient profiling systems: are science and the consumer connected. Am J Clin Nutr. 2010. Vol. 91 no. 4 (April).p: 1116S-1117S.

FAO. 2008. FAO News Lette.

Kemendes. 2015. Pengembangan Sumberdaya dan Lingkungan Hidup (PSDLH) KEMENDES.

Leganger, A. 2003. Control Constructs: Do They Mediate the relation between educational attainment and health behaviour. J Health Psychol. 2003. Vol. 8 no. 3 (May). p: 361372.

Maillot, M., N. Darmon, F. Vieux and A. Drewnowski. 2007. Low energy density and high nutritional quality are each associated with higher diet costs in French adults. Am J of Clin Nutr. 2007. Vol. 86, No. 3 (Sept). p: 690-696.

Massie, D. 2001. Metode Penelitian Sosial Ekonomi. Umi Aksara.

Mikolajczyk, R.T.,W. El Ansari and A.E Maxwell. 2009. Food consumption frequency and perceived stress and depressive symptoms among students in three European countries. Nutr J. 2009.

Nilsen, S.M., S. Krokstad, T.L. Holmen, and S. Westin. 2010. Adolescents' health-related dietary patterns by parental socio-economic position, The Nord-Trøndelag Health Study (HUNT). Eur J Public Health. 2010. 20 (3). p: 299-305. 
Osak, R.A.F., V.V.J. Panelewen., J. Pandey dan I.D.R. Lumenta. 2014. Pengaruh Pendapatan Rumahtangga terhadap Konsumsi Daging (Sapi, Babi dan Ayam) di Desa Sea I Kecamatan Pineleng. Jurnal Zootek Vol 34 (2) : 10-17.

Rachman, H.P.S. 2001. Kajian Pola Konsumsi dan permintaan pangan masyarakat berpendapatan pendah Jawa Tengah dan Nusa Tenggara Barat. jurnal Agro Ekonomi : 15 (2) : 36-53. Pusat Penelitian Sosial Ekonomi. Bogor.

Rasyaf, M., 2000. Memasarkan Hasil Peternakan. Penebar Swadaya, Jakarta.

Sandvik, C., R. Gjestad, O. Samdal, J. Brug, and K.I. Klepp. 2010. Does socio-economic status moderate the associations between psychosocial predictors and fruit intake in schoolchildren? The Pro Children study. Health Educ. Res. 2010. 25 (1). p: 121-134.

Sayekti, A. A. 2008. Pola Konsumsi Pangan Rumah Tangga di Wilayah Historis Pangan Beras dan Non Beras di Indonesia. Institut Pertanian Yogjakarta. Yogyakarta.

Sugiarto, T., Herlambang, Bugiarto, R. Sudjan dan S. Kelana. 2002. Ekonomi Mikro (Sebuah Kajian Komprehensif). Gramedia. Jakarta

Susenas, BPS, 2014. Perkembangan Konsumsi Daging Sapi di Indonesia Tahun 1993 - 2014.

Suyastiri Y.P, N.M. 2008. Difersifikasi Pangan Pokok BerbasisPotensi Lokal Dalam Mewujudkan Ketahanan Pangan Rumah Tangga Pedesaan di Kecamatan Semin, Kabupaten Gunung Kidul. Jurnal Ekonomi Pembangunan.
Tanziha, I. 2009. Goal Programming: optimalisasi konsumsi pangan balita pada keluarga nelayan. J Gizi dan Pangan. 2009. 4(1) (Maret). p: 1 7.

Vereecken, C.A., J. Inchley, S.V. Subramanian, A. Hublet and L. Maes. 2005. The relative influence of individual and contextual socioeconomic status on consumption of fruit and soft drinks among adolescents in Europe. Eur J Public Health. 2005. 15 (3) (June). p: 224232.

Wangberg, S.C., H.K. Andreassen, H. Prokosch, S.M.V. Santana, T. Sørensen and C.E. Chronaki. 2008. Relations between Internet use, socio-economic status (SES), social support and subjective health. Health Promot. Int. 2008. 23 (1). p: 70-77. 